\title{
Nitrate leaching and productivity of some farming options in the Lake Taupo catchment
}

\author{
K. BETTERIDGE ${ }^{1}$, C.J. HOOGENDOORN ${ }^{1}$, B.S. THORROLD ${ }^{3}$, D.A. COSTALL ${ }^{1}$, S.F. LEDGARD ${ }^{2}$, \\ Z.A. PARK-NG ${ }^{1}$, and P.W. THEOBALD ${ }^{1}$ \\ ${ }^{1}$ AgResearch Grasslands, PB 11008, Palmerston North \\ ${ }^{2}$ AgResearch, Ruakura Research Centre, $P B$ 3123, Hamilton \\ ${ }^{3}$ Dexcel, PB 3221, Hamilton \\ keith.betteridge@agresearch.co.nz
}

\begin{abstract}
To farm efficiently within a nitrogen $(\mathrm{N})$ cap, Taupo farmers need to know the relative $\mathrm{N}$-leaching potential of existing and potential farming enterprises. We quantified production and $\mathrm{N}$ leaching in four 'cut and carry' cropping treatments (Trial 1), and two cattle grazing systems (Trial 2), in replicated trials over 3 years. Annual crop systems Triticale and Maize, which included annual ryegrass as a winter cover crop, leached 104 and 222 (1 year only) $\mathrm{kg}$ nitrate-N/ha respectively, while perennial crops Lucerne and Pasture leached 19 and $12 \mathrm{~kg}$ nitrate$\mathrm{N} / \mathrm{ha} / \mathrm{yr}$ respectively. In grazing systems, removing cattle between May and August reduced N-leaching from 13 to $5 \mathrm{~kg}$ nitrate-N/ha/yr and could be achieved by strategic selling and buying, grazing-off, or using feed-pad systems. N-fertilised annual crops, can lead to high $\mathrm{N}$ leaching whereas in cattle grazing systems, strategic destocking over winter can greatly reduce $\mathrm{N}$ leaching. Some enterprise choices based on quantified $\mathrm{N}$ leaching data can now be made.
\end{abstract}

Keywords: cropping, lucerne, maize, triticale, cattle grazing, nitrogen leaching, environment

\section{Introduction}

Variation 5 to Environment Waikato's Regional Plan requires farmers in the Lake Taupo catchment to farm within a N leaching cap (Environment Waikato 2007). Therefore, future increased productivity must come from greater $\mathrm{N}$ efficiency of existing enterprises or by using new enterprises that leach less $\mathrm{N}$. Trials were instigated to determine forage production and $\mathrm{N}$ leaching using several options available to farmers. Nitrogen leaching losses from grazed pastures can range from 10 to $200 \mathrm{~kg}$ $\mathrm{N} / \mathrm{ha} / \mathrm{yr}$ depending on stocking intensity and level of inputs (Ledgard 2001). Animal urine patches are the main source of $\mathrm{N}$ leaching and losses occur predominantly over the winter period (Ledgard et al. 2007). Strategies were chosen that might reduce this source of $\mathrm{N}$ loss. Farmers required that the test options had a proven ability to affect $\mathrm{N}$ cycling and were relevant to farmers in the catchment. On this basis we investigated: (1) growing annual and perennial forage crops for sale off-farm, or for use in feedlots on-farm with summer disposal of effluent to pasture; and (2) removing cattle from pasture during winter.

\section{Methods}

Evaluation of forage cropping was carried out on WaituhiKuratau Farm, and the winter grazing management strategies were evaluated on near-by Rangiatea Station. These farms are close to Kuratau Junction on SH 32, on the western side of Lake Taupo. The dominant soils were moderately rolling, deep, very free-draining Oruanui Sand (Podzolic Orthic Pumice, W.C. Rijkse, pers. comm.).

Treatments were established in spring 2002 on plots ranging in size from $0.7-1.1$ ha, using a randomised complete block design, with three blocks, at each of the two sites. The Cropping site had been cultivated and sown in summer 2001-2 with a short rotation ryegrass which was sprayed out before cultivation in September 2002 , in preparation for planting trial crops. The Grazing site had been cultivated in about 1995 and sown with new pasture species. This site was maintained in its current state.

\section{Cropping trial}

Two annual and two perennial crops were compared. We aimed to achieve the yield potential from these forage crops by applying high rates of fertiliser in split applications. Initial tests on the Cropping site showed soil $\mathrm{pH}$ and $\mathrm{P}$ levels were lower than optimal for high yielding crops, especially lucerne. Capital inputs of lime increased soil $\mathrm{pH}$ to 6.3 in lucerne ( $5 \mathrm{t}$ lime/ha) and to 6.0 in other treatments $(2.5 \mathrm{t}$ lime/ha). Olsen $\mathrm{P}$ was maintained at $>40$. Sowing dates and methods are summarised in Table 1 and average annual fertiliser rates are given in Table 2.

Triticale $^{1}$ (cv. Doubletake, $190 \mathrm{~kg} / \mathrm{ha}$ ). This high yielding cereal silage crop was considered better suited than maize to the short growing season at Kuratau. As cultivation releases $\mathrm{N}$ from mineralisation of soil organic matter (Rotz et al. 2005), we direct-drilled triticale in 
spring of Years 2 and 3 and direct-drilled the annual grass (cv. Feast II, $28 \mathrm{~kg} / \mathrm{ha}$ ) into triticale stubble in autumn of Years 1 to 3 , to minimise the risk of $\mathrm{N}$ leaching. Before spring sowing the ryegrass was sprayed out with glyphosate. Triticale was sown with DAP and received $\mathrm{N}$ and $\mathrm{K}$ once or twice after sowing of triticale and once or twice after sowing of annual ryegrass. In spring 2004, an inadvertent double application of DAP was given to triticale at sowing ( $108 \mathrm{v} 54 \mathrm{~kg} \mathrm{~N} / \mathrm{ha}$ ) because the crop had to be re-sown due to poor establishment. This resulted in a higher application of $\mathrm{N}$ than in Years 1 and 3. Higher annual applications of $\mathrm{N}$ were given each year in an attempt to obtain yield potential. Triticale was harvested in late January-early February at the milk-dough stage. The harvested crop was wilted to about $40 \%$ dry matter content, and baled.

Maize (cv. Pioneer 38F70, 110000 seed/ha) was sown in paired-rows with pre-emergent pesticides and herbicides under a bio-degradable plastic film, anchored at the edges by soil. This technology is used to allow earlier sowing in cold environments where the length of the growing season is marginal for maize. In Year 1, only one plot of maize was 'observed' whereas three replicate plots were sown in Year 2. N leaching was measured in Year 2 only. This crop was planted following full cultivation in both years, as a very fine tilth is required to ensure the plastic film is adequately anchored to the ground with little risk of ripping. In March, maize was fine-chopped and stored in a silage 'bun' where it was compacted by tractor and then covered with plastic weighted down with tyres.

Lucerne (cv. Kaituna; $12 \mathrm{~kg} / \mathrm{ha}$ ) was chosen for its high value; large root mass and deep rooting characteristics (Ward et al. 2002) and low need of fertiliser N. Lucerne received a September application of $20 \mathrm{~kg}$ $\mathrm{N} /$ ha to boost early growth in Years 2 and 3. Lucerne was cut at late bud-early flowering, to minimise possible damage to new tillers, wilted to about $25-30 \%$ dry matter (DM) and baled into round, plastic-wrapped bales. The final Lucerne cut was made in March or April of each year, to ensure a build up of root reserves before dormancy, for next season's growth.

Pasture (ryegrass, cv. Quartet $24 \mathrm{~kg} / \mathrm{ha}$; red clover, cv. Kopu II, $2 \mathrm{~kg} / \mathrm{ha}$, and white clover cv. Challenge, 2

Table 1 Details of site preparation and sowing dates of annual and perennial crops, and harvest dates of Maize in the Cropping trial.

Site preparation, September Year 1: Glyphosate-sprayed resident pasture, power-harrowed, basal lime and fertiliser applied, rolled, seed sown, rolled.

\begin{tabular}{|c|c|c|c|c|}
\hline & Sowing method & \multicolumn{3}{|c|}{ Sowing dates } \\
\hline \multicolumn{5}{|l|}{ Annual crops } \\
\hline Triticale + & Direct-drilled & 15 Oct 02 & $\begin{array}{l}20 \text { Sep }^{1} \text { and } \\
25 \text { Oct } 03\end{array}$ & 20 Oct $04^{1}$ \\
\hline annual ryegrass & Direct-drilled & 20 Mar 03 & 14 Feb 04 & 5 Mar 05 \\
\hline Maize sown & MUP2 $^{2}$ & 15 Oct 02 & 16 Oct $03^{1}$ & Not sown \\
\hline harvested & & 14 Mar 03 & 18 Mar 04 & \\
\hline \multicolumn{5}{|l|}{ Perennial crops } \\
\hline Lucerne & $\begin{array}{l}\text { Surface sown, chain- } \\
\text { harrowed and rolled }\end{array}$ & 15 Oct 02 & & \\
\hline Pasture & $\begin{array}{l}\text { Surface sown, chain- } \\
\text { harrowed and rolled }\end{array}$ & 15 Oct 02 & & \\
\hline \multicolumn{5}{|c|}{$\begin{array}{l}\text { Glyphosate-sprayed before sowing. }{ }^{2} \mathrm{MUP} \text { - maize under plastic, sown with pre-emergent herbicide, insecticide and seed under bio- } \\
\text { degradable plastic film. Weeds in each treatment were controlled with herbicides. }\end{array}$} \\
\hline \multirow[t]{2}{*}{ Treatment } & Mean rate applied (kg/ha) & & & \\
\hline & $\mathrm{N}$ & $\mathrm{P}$ & $\mathrm{K}$ & $\mathrm{S}$ \\
\hline \multicolumn{5}{|l|}{ Cropping trial } \\
\hline Triticale & 246 & 81 & 157 & 52 \\
\hline Lucerne & 13 & 93 & 239 & 104 \\
\hline Pasture & 204 & 57 & 141 & 40 \\
\hline Maize (Years 1\&2) & $285^{1}$ & 114 & 300 & \\
\hline \multicolumn{5}{|l|}{ Grazing Trial } \\
\hline No grazing & 60 & 10 & 81 & 20 \\
\hline
\end{tabular}

${ }^{1} 100 \mathrm{~kg} \mathrm{~N} / \mathrm{ha}$ as 'Sustain' urea at planting; $185 \mathrm{~kg} \mathrm{~N} / \mathrm{ha}$ as side-dressing in December. 
$\mathrm{kg} / \mathrm{ha}$ ). High quality perennial species were sown as the control. Sowing methods and dates are detailed in Table 1. Pasture was fertilised with $\mathrm{N}$ and $\mathrm{K}$ following each cut in Years 1 and 2. Lower than expected yields and visual signs of $\mathrm{N}$ deficiency led to monthly applications of $30 \mathrm{~kg} \mathrm{~N}$ and $25 \mathrm{~kg} \mathrm{~K} /$ ha being made in Year 3, except in June and July when leaching potential was greatest and soils were too cold for plant growth. Pasture was harvested at a nominal cover of $2500 \mathrm{~kg} \mathrm{DM} / \mathrm{ha}$, wilted to about $25-30 \%$ dry matter (DM) and baled into round, plastic-wrapped bales.

Yield and quality measurements All bales of Pasture, Lucerne and Triticale were weighed. Three bales from each plot at each harvest were core-sampled with the three-bale composite sample analysed for DM, metabolisable energy (ME) and $\mathrm{N}$ contents. Maize yield was determined by sampling standing biomass in $5 \mathrm{x} 1$ $m$ rows in three positions within each replicate, followed by drying and weighing. Core samples were taken from the maize silage bun for $\mathrm{N}$ and $\mathrm{ME}$ content assessment.

\section{Grazing trial}

All-Year rotational Grazing of cattle $(A Y G)$, which is typical management for a cattle finishing block, was compared to No Winter Grazing $(N W G)$ in which cattle were rotationally grazed as in $A Y G$, except that cattle were removed from May until early September, as may occur with a cattle-trading regime. No Grazing $(N G)$ was a low-fertility strategy of cut and carry.

$A Y G$ plots were grazed 8-9 times/yr whereas $N W G$ received two less grazings/yr. Winter-grown pasture in $N W G$ was carried forward to September when it was grazed by cattle. Replicate paddocks of $A Y G$ and $N W G$ were grazed consecutively. Three to four cuts of baleage/ yr were taken from $N G$.

Yield and quality measurements Pre- and post-grazing pasture mass was determined by rising plate meter to estimate DM utilisation. Pre-grazing pasture $\mathrm{N}$ and ME content was assessed on hand-plucked pasture from within each plot, except for $N G$ which was sampled as for Pasture.

\section{Nitrogen leaching}

Nitrogen leaching was calculated as the product of soil solution $\mathrm{N}$ concentration in ceramic suction cup samplers (600 mm depth; Lord \& Shepherd 1993) and drainage volume determined by a water balance model for each site. Cups were installed in March 2003, after establishment of the treatments in the previous spring. The cups captured the first drainage after the drought but missed any drainage occurring between sowing and the end of December 2002. The Cropping trial had 10 cup samplers/plot, and the Grazing trial 20 cup samplers/ plot. Leachate sampling occurred once accumulated drainage exceeded $40 \mathrm{~mm}$. Individual leachate samples were analysed for nitrate- $\mathrm{N}$ and ammonium-N to ISO standards using flow injection analyses.

\section{Statistical analyses}

Data were analysed in GenStat (2006) using an Analysis of Variance with Crop/Grazing treatment, and Year and their interaction fitted as treatment terms, and Blocks as a blocking term. The amount of nitrate leached was calculated as the average concentration over all ceramic cups per plot at each sampling time (excluding missing values), averaged over each pair of successive time points, multiplied by the drainage over this time period, and then summed for each year. Nitrate leaching data for each plot were then square-root transformed so that the variances for all treatments were homogenous, with backtransformed means presented in this paper. Maize was not included in the analyses as the three Blocks used for this treatment in Year 2 were not randomly positioned with respect to all of the other treatments.

\section{Results and Discussion}

Between sowing in October 2002 and late January 2003, $354 \mathrm{~mm}$ rain fell, but only $88 \mathrm{~mm}$ fell from then until late April. This low summer/autumn rainfall slowed establishment of Lucerne and Pasture treatments whereas the triticale was probably unaffected. Conversely, 200304 (Year 2) was extremely wet, with unusually high summer rainfall (400 $\mathrm{mm}$ in February), and annual rainfall was $80 \%$ greater than in 2002-03 (Year 1).

\section{Rainfall and drainage (Fig. 1)}

As rainfall and drainage were similar at the two sites (inset Tables in Fig. 1), only monthly data from the Cropping trial are shown. Since samplers were installed in March 2003, any drainage and leaching between sowing and the end of December 2002 was not recorded. Significant $\mathrm{N}$ loss may have occurred during this period as a result of mineralisation of soil organic matter following desiccation and cultivation of the previous pasture. The majority of any possible $\mathrm{N}$ leaching loss would have been similar across all plots as newly applied fertiliser $\mathrm{N}$ is unlikely to have leached to the $600 \mathrm{~mm}$ depth with the $77 \mathrm{~mm}$ of drainage (estimated from the $354 \mathrm{~mm}$ rainfall less the $273 \mathrm{~mm}$ PET (average of the next three October-December periods)) that probably occurred between 1 October and 31 December 2002. The low January and February Year 1 rainfall would not have resulted in drainage.

\section{Cropping trial forage production (Table 3)}

Triticale The most consistent DM yield over the 3 years of the trial was from triticale with annual ryegrass due mainly to the relatively high yield of triticale in Year 1 
Figure 1 Monthly rainfall and drainage at the Cropping trial. Annual totals for both trials are inset as tables.

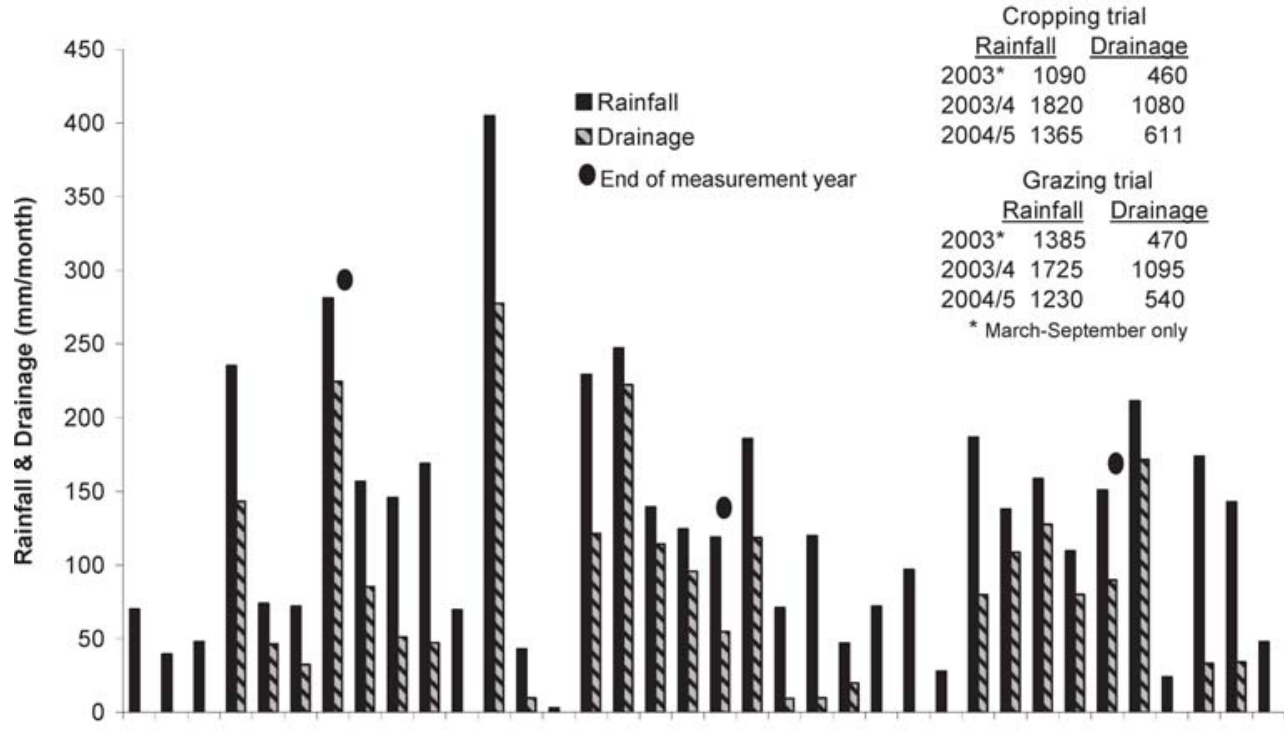

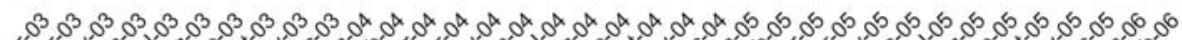

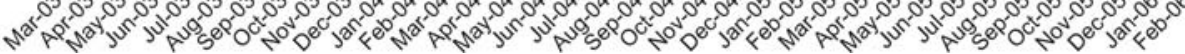

which established better before the Year 1 summer drought commenced, compared with either Lucerne or Pasture. Triticale's highest yield, in Year 3, can be attributed to the high production from the annual ryegrass compared with that from the two earlier winters when the annual ryegrass crop was not harvested (data not shown). Triticale yield was always well below the expected growth potential of $14 \mathrm{t} \mathrm{DM} / \mathrm{yr}$ that the crop was fertilised to produce. Given that fertiliser was not limiting, and that in Year 2 maize-under-plastic did yield to potential, it seems that climatic conditions limited triticale growth at this site. Sowing date was based on 'local' experience, but in retrospect was perhaps too late for the yield potential to be achieved. Because maturity is very rapid, there was no scope to delay harvest for increased yield without compromising quality of this green-feed crop. Production was not affected by disease. Triticale baleage had only 8 to $10 \mathrm{MJ} \mathrm{ME} / \mathrm{kg} \mathrm{DM} / \mathrm{yr}$, which cannot be considered adequate for maintenance feeding of livestock. Protein content was also low, but this was expected given the late stage of growth at which harvesting took place. Poor crop quality would have been accentuated by the difficulty experienced in compacting mature triticale into round bales and the practical difficulties in harvesting the crop during the very short window-of-opportunity when quality and yield are optimal (M. van Plateringen pers. comm.).

Maize In Year 1, half of the paired-row plastic film strips blew away within the first 1 to 3 weeks thereby removing the 'greenhouse' effect on early growth and the protection of maize seedlings from frost. Where the plastic remained intact, many dead plants were found due to over-heating before they could break through the plastic. Only $11 \mathrm{t} \mathrm{DM} / \mathrm{ha}$ was grown in that year. With less wind and a different grade of plastic in Year 2, no plastic blew away and no plants died from over-heating. This maize-under-plastic technology enabled the target $22 \mathrm{t} \mathrm{DM} /$ ha crop to be achieved. Without this technology, maize is not grown in this environment. As expected, crude protein content (7.3\%) was low but ME was high (10.8 MJ ME $/ \mathrm{kg}$ DM). Harvested N was estimated to be $248 \mathrm{~kg} \mathrm{~N} / \mathrm{ha}$.

Pasture production in the Cropping trial was low in the first year due to slow establishment but increased through to Year 3. In all years, production fell short of the $14 \mathrm{t} \mathrm{DM} / \mathrm{ha} / \mathrm{yr}$ target for which it was fertilised. Ignoring Year 1 data, average Pasture yield was about $1000 \mathrm{~kg} \mathrm{DM} /$ ha greater than the DM yield from $N G$ in the grazing trial. This difference can be explained by the $7.1 \mathrm{~kg} \mathrm{DM} / \mathrm{kg} \mathrm{N}$ fertiliser response to the additional 140 $\mathrm{kg} \mathrm{N}$ applied in the Pasture compared to the $N G$ treatment. We are unable to explain the poor annual pasture production as soil test results and regular high $\mathrm{N}$ applications indicated nutrients were not limiting production. Pasture baleage quality was high, being 10.8 - 12.7 MJ ME/kg DM and $12-22 \%$ crude protein respectively.

Lucerne production increased each year with the highest production (11.5 t DM/yr) in Year 3. After the establishment year, Lucerne had significantly higher annual production than other treatments. In a frost-prone valley near Wairakei, Baars et al. (1975) measured a 5- 
Table 3 Dry matter production of crops and pasture ( $\mathrm{kg} \mathrm{DM} / \mathrm{ha} / \mathrm{yr})$ in the Cropping and Grazing trials.

\begin{tabular}{|c|c|c|c|c|}
\hline Treatment & $2002-2003$ & 2003-2004 & 2004-2005 & $\begin{array}{l}\text { Mean annual } \\
\text { production }\end{array}$ \\
\hline \multicolumn{5}{|l|}{ Cropping trial } \\
\hline Triticale & 7880 a (1) & 6835 c (1) & 9160 b (2) & 7960 a \\
\hline Lucerne & 450 c (1) & 7615 a (4) & 11455 a (3) & $6510 \mathrm{~b}$ \\
\hline Pasture & 2590 b (4) & 6035 b (3) & 9885 b (4) & $6170 \mathrm{~b}$ \\
\hline Maize $^{1}$ & ca.11000 & 22000 & not sown & \\
\hline \multicolumn{5}{|c|}{$\begin{array}{l}\text { (n) }=\text { number of cuts. Year effect } P<0.001, L S D=445 ; \text { Treatment effect } P<0.005, L_{S D} D_{0.05}=561 ; \text { Treatment }{ }^{*} Y \text { ear } P<0.001 \text {, } \\
L S D_{0.05}=749 \text { (treatment within years). Lower case letters are for comparison of treatment means within years and for } \\
\text { comparison of mean annual production. } \\
{ }^{1} \text { Not included in statistical analyses }\end{array}$} \\
\hline \multicolumn{5}{|l|}{ Grazing trial } \\
\hline All year grazing & $5125 \mathrm{a}$ & $5425 a b$ & $10348 \mathrm{a}$ & 6966 a \\
\hline No winter grazing & $4390 a b$ & $4805 \mathrm{~b}$ & 9403 a & $6199 \mathrm{~b}$ \\
\hline No grazing & 3199 b (3) & 6804 a (4) & 7580 b (3) & $5861 \mathrm{~b}$ \\
\hline
\end{tabular}

Table 4 Annual leached nitrate- and ammonium- $\mathrm{N}$ in the Cropping and Grazing trials (kg N/ha/yr). Statistical analyses were based on square root transformed means, with back-transformed mean values presented here.

\begin{tabular}{|c|c|c|c|c|c|c|c|c|}
\hline & \multicolumn{2}{|c|}{$-2002-2003^{1}-$} & \multicolumn{2}{|c|}{$-2003-2004-$} & \multicolumn{2}{|c|}{$-2004-2005-$} & \multicolumn{2}{|c|}{ - Mean -} \\
\hline & $\mathrm{NO}_{3}-\mathrm{N}$ & $\mathrm{NH}_{4}-\mathrm{N}$ & $\mathrm{NO}_{3}-\mathrm{N}$ & $\mathrm{NH}_{4}-\mathrm{N}$ & $\mathrm{NO}_{3}-\mathrm{N}$ & $\mathrm{NH}_{4}-\mathrm{N}$ & $\mathrm{NO}_{3}-\mathrm{N}$ & $\mathrm{NH}_{4}-\mathrm{N}$ \\
\hline \multicolumn{9}{|l|}{ a) Cropping trial } \\
\hline Lucerne & $10 \mathrm{~b}$ & 0.8 & $24 b$ & 1.5 & $22 b$ & 2.0 & $19 b$ & 1.2 \\
\hline Pasture & $8 \mathrm{~b}$ & 0.5 & $10 \mathrm{c}$ & 1.2 & $19 b$ & 1.8 & $12 \mathrm{c}$ & 1.0 \\
\hline Triticale & $45 \mathrm{a}$ & 0.7 & $164 \mathrm{a}$ & 2.4 & $107 \mathrm{a}$ & 2.0 & $104 \mathrm{a}$ & 1.4 \\
\hline Maize & not sampled & & $222^{2}$ & $2.5^{2}$ & & not sample & & \\
\hline \multicolumn{9}{|l|}{ b) Grazing trial } \\
\hline All year grazing (AYG) & $19.0 \mathrm{a}$ & 0.9 & $16.9 \mathrm{a}$ & 1.1 & 4.0 & 1.2 & $12.2 \mathrm{a}$ & 1.1 \\
\hline No winter grazing (NWG) & $2.6 \mathrm{~b}$ & 0.8 & $9.9 a b$ & 1.6 & 2.3 & 1.1 & $4.4 \mathrm{ab}$ & 1.0 \\
\hline No grazing (NG) & $1.0 \mathrm{~b}$ & 0.5 & $3.9 \mathrm{~b}$ & 1.6 & 0.8 & 1.0 & $1.7 \mathrm{~b}$ & 1.2 \\
\hline
\end{tabular}

year average annual lucerne production of $13.5 \mathrm{t} \mathrm{DM} / \mathrm{ha}$. This indicates that lucerne's growth potential in the present trial was probably not achieved. In the present and the Wairakei trials, average pasture production was 6170 and $7500 \mathrm{~kg} \mathrm{DM} / \mathrm{ha} / \mathrm{yr}$ respectively - in both cases being lower than the Lucerne yields. Lucerne baleage quality was generally high, ranging from 8.5-11.9 MJ $\mathrm{ME} / \mathrm{kg} \mathrm{DM}$ and $18-30 \%$ crude protein. Only two cuts of baleage had ME values $<10$.

\section{Grazing trial forage production (Table 3)}

Pasture production was $16 \%$ higher in $A Y G$, probably because of the extra two grazings over winter, compared to the average $N W G$ and $N G$ production which both would have experienced more plant death and leaf decay over this time. The low yield of the winter-spelled pasture $(N W G, N G)$ clearly represents a cost to this system that would need to be compensated for by other benefits for it to be a viable management option in comparison to $A Y G$.

\section{Nitrogen leaching (Table 4)}

Perennial crops leached between 8 and $26 \mathrm{~kg}$ nitrate-N/ ha/yr, with Lucerne leaching the same or slightly more nitrate-N/ha than Pasture. Because of the late installation of ceramic cups, total leaching in Year 1 would have been under-estimated.

Ammonium-N losses were very small and similar amongst treatments, and contributed a high proportion of total $\mathrm{N}$ leaching loss only where nitrate losses were small ( $N G$, Table $4 \mathrm{~b})$.

Triticale leached 5 to 16 times more nitrate-N than the perennial crops, with most (164 kg nitrate-N/ha) leached in Year 2 when $460 \mathrm{~mm}$ rain fell in February alone. Not only was too much fertiliser $\mathrm{N}$ applied relative to actual requirements for the lower-than-expected yield, but heavy rain also fell between Triticale harvest and establishment of the annual ryegrass in Year 2, which would have maximised the opportunity for $\mathrm{N}$ leaching. Poor growth of autumn ryegrass in each of the three cool-season periods would have provided little potential to utilise the 
available $\mathrm{N}$ from mineralisation of the crop residues, soil organic matter and fertiliser $\mathrm{N}$ applied at and after sowing of this annual grass.

Maize leached more than $220 \mathrm{~kg}$ nitrate-N/ha in Year 2 , the only year when leaching measurements were made in this treatment. Of this, $43 \%$ was leached during the growing season. Maize was established following full cultivation, had $285 \mathrm{~kg} \mathrm{~N}$ fertiliser/ha applied and had $248 \mathrm{~kg} \mathrm{~N} /$ ha harvested. By simple N balance, $183 \mathrm{~kg}$ of the sum of $\mathrm{N}$ accounted for by leaching + harvesting must have been derived from mineralised organic matter. Foundation for Arable Research fact sheets (FAR 2006b) show very little fertiliser $\mathrm{N}$ is needed for a first maize crop that follows cultivation of a long-term pasture. Also, FAR studies have shown that maize can capture a significant amount of mineral $\mathrm{N}$ between $600 \mathrm{~mm}$ (ceramic cup depth) and $1.8 \mathrm{~m}$ (FAR 2006a) soil depth$\mathrm{N}$ that we have reported as having leached. However, during winter when most leaching takes place and maize is dead, the $\mathrm{N}$ below $600 \mathrm{~mm}$ depth is likely to have leached through this pumice soil before a subsequent crop could capture it.

While it is not valid to statistically compare treatments between trials, $N G$ in the grazing trial leached some 10 $\mathrm{kg} / \mathrm{ha} / \mathrm{yr}$ less $\mathrm{N}$ than did Pasture in the cropping trial. This probably reflected cultivation effects with establishment of Pasture and the greater amount of $\mathrm{N}$ fertiliser applied to Pasture.

The importance of $\mathrm{N}$ leaching from grazed pasture is illustrated in this trial with $A Y G$ leaching four times more $\mathrm{N}$ than $N G$. $N W G$ was intermediate. During the wet summer of 2003-2004, N leaching was similar in both grazing treatments. But, by removing cattle between May and late August in all 3 years, $\mathrm{N}$ leaching was greatly reduced during these wet months, with $N W G$ being close to $N G$ in $\mathrm{N}$ leaching pattern.

Leaching in Year 3 was lower than in Years 1 and 2. The most likely explanation is that the wetting up of soil in autumn of Year 3 was more gradual than in the previous 2 years, thus allowing a greater retention of urinary- $\mathrm{N}$ by plants, soil and soil microbes, before it could be leached as nitrate.

\section{Conclusions}

The Cropping trial yields varied greatly due to weather and site factors. The maize-under-plastic technology illustrated that the site had a high yield potential only when temperature limitations were overcome through use of this mini-greenhouse. Lucerne yields, even in Year 3, were below target, yet the yield advantage over perennial Pasture illustrates the extent of moisture limitation on the site. Triticale crop yields were also well below target, even though there should have been adequate early-season rainfall for good growth of this quick-maturing crop. But, given the high yield of Maize, it seems more likely that poor performance of triticale was due to lack of adequate temperature in its growing season. The higher yield of the newly established perennial pasture at the cropping site over the existing pasture at the grazing site can be explained by the difference in general soil fertility, age of the pasture, different cultivars and $\mathrm{N}$ inputs between the two sites.

$\mathrm{N}$ leaching results showed the risks associated with high $\mathrm{N}$ fertiliser inputs combined with cropping systems lacking permanent plant cover (Allingham et al. 2002). Maize and Triticale both showed high leaching losses probably as a result of periods of low vegetative cover and high application rates of fertiliser N. This was especially so when $\mathrm{N}$ fertiliser was applied during the Year 2 growing season which had significant summer drainage. Given the low yield of Triticale, leaching losses from this crop could have been reduced if we had adopted a fertiliser regime aimed at a more realistic yield for the present environment and had accounted for current soil profile N. It is recommended that farmers growing maize crops sample soil mineral $\mathrm{N}$ content to $1.8 \mathrm{~m}$ depth before devising their fertiliser plan (FAR 2006a).

Given low N inputs, Lucerne gave higher than expected $\mathrm{N}$ leaching losses. This may be due to organic matter mineralisation and lucerne's $\mathrm{N}$-fixing ability. As relatively high yields and quality were obtained from established lucerne, more $\mathrm{N}$ leaching research with this crop is warranted.

Heavily fertilised perennial Pasture resulted in moderate $\mathrm{N}$ leaching losses, but most probably much less than would have occurred if this crop had been grazed rather than harvested. As with Triticale, rates of $\mathrm{N}$ fertiliser that were more closely matched to target yields for the environment may have reduced $\mathrm{N}$ leaching from Pasture, perhaps with little impact on yield. This is illustrated by comparison with the results from the grazing trial where leaching losses were $80 \%$ less than those in the cropping trial, while yields were only $12 \%$ lower with $70 \%$ less $\mathrm{N}$ fertiliser used.

The influence of grazing animals on $\mathrm{N}$ leaching is clearly seen in the grazing trial. Where the animals were removed (NG), leaching was very low. With the animals removed over the winter period, leaching was substantially reduced, although during a wet summer, $\mathrm{N}$ can be leached regardless of the winter grazing management.

\section{ACKNOWLEDGEMENTS}

This project was funded by Sustainable Farming Fund, Puketapu Group, FertResearch, Dairy InSight and Environment Waikato. Puketapu Group staff provided valuable support to the project at administrative and 
operational levels. In particular we thank Alan Lower and Colin Gates for assistance with Grazing Trial management and Mike Devlin for assistance with the Cropping Trial. Agricultural contracting was done by Truebridge Contractors and Wyllie Sprayers and research was conducted by AgResearch and Dexcel. Genetic Technologies funded and advised on the maize trial and management advice was offered by Ravensdown, Ballance Agri-nutrients and Wrightson staff. Conception of the project was assisted by Dr Greg Lambert, AgResearch Grasslands, Palmerston North; field assistance was provided by Laura Bailey, Judy Devlin and Margaret Hughes, Kuratau, and by Amanda Judge, Mike Sprosen, Stuart Lindsay and Moira Dexter from AgResearch, Ruakura.

\section{REFERENCES}

Allingham, K.D.; Cartwright, R.; Donaghy, D.; Conway, J.S.; Goulding, K.W.T.; Jarvis, S.C. 2002. Nitrate leaching losses and their control in a mixed farm system in the Cotswold Hills, England. Soil Use and Management 18: 421-427.

Environment Waikato 2007. How Land Use Affects Taupo. Regional Plan, Variation 5._http:// www.ew.govt.nz/enviroinfo/water/lakes/laketaupo/ landuseaffectslaketaupo.htm Cited 01.05.2007.

FAR (Foundation for Arable Research). 2006a. No. 36.
Early leaching of nitrate in maize paddocks;

FAR 2006b. No. 41, $\mathrm{N}$ fertiliser response in a high soil $\mathrm{N}$ environment in Northland. http://far.org.nz/front

FAR 2007. Maize: No. 48, AmaizeN, a forecaster for nitrogen management in maize - results from Year 1. http://far.org.nz/front

GenStat 2006. GenStat for Windows. Release 9.0. Ninth Edition. VSN International Ltd., Oxford

Ledgard, S.F. 2001. Nitrogen cycling in low input legume-based agriculture, with emphasis on legume/ grass pastures. Plant and Soil 228: 43-59.

Ledgard, S.F.; Welten, B.; Menneer, J.; Betteridge, K.; Crush, J.R.; Barton, M.D. 2007. New nitrogen mitigation technologies for evaluation in the Lake Taupo catchment. New Zealand Grassland Association 69: 117-121.

Lord, E.I.; Shepherd, M.A. 1993. Developments in the use of porous ceramic cups for measuring nitrate leaching. Journal of Soil Science 44: 435-449.

Rotz, C.A.; Taube, F.; Russelle, M.P.; Oenema, J.; Sanderson, M.A.; Wachendorf, M. 2005. Whole-farm perspectives of nutrient flows in grassland agriculture. Crop Science 45: 2139-2159.

Ward, P.R.; Dunin, F.X.; Micin, S.F. 2002. Water use and root growth by annual and perennial pastures and subsequent crops in a phase rotation. Agricultural Water Management 53: 83-97. 